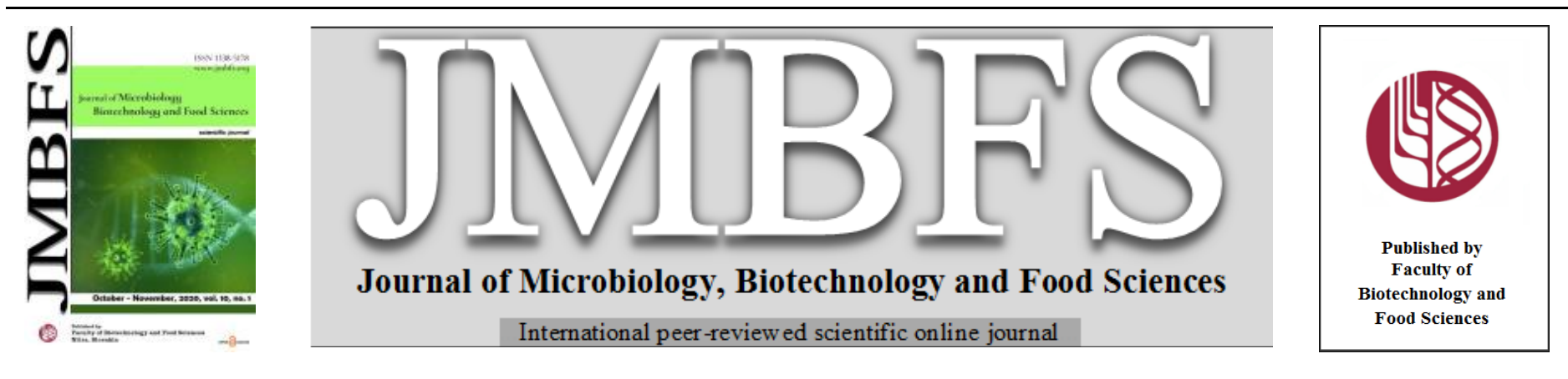

\title{
EFFECT OF ADDITION OF SPELT AND BUCKWHEAT HULL ON SELECTED PROPERTIES OF YOGHURT
}

\author{
Agata Znamirowska ${ }^{l}$, Katarzyna Sajnar ${ }^{l}$, Magdalena Kowalczyk ${ }^{l}$, Maciej Kluz ${ }^{2}$, Magdalena Buniowska ${ }^{*}$
}

Address(es):

${ }^{1}$ University of Rzeszow, Faculty of Biology and Agriculture, Department of Dairy Technology, Ćwiklińskiej 2D, 35-601 Rzeszów, Poland, phone number: +48177854905 .

${ }^{2}$ University of Rzeszow, Faculty of Biology and Agriculture, Department of Bioenergetics and Food Analysis, Ćwiklińskiej 1, 35-601 Rzeszów, Poland.

*Corresponding author: mbuniowska@ur.edu.pl

doi: $10.15414 /$ jmbfs.2020.10.2.296-300

\section{ARTICLE INFO}

Received 23. 5. 2019

Revised 24. 6. 2020

Accepted 29. 6. 2020

Published 1. 10. 2020

Regular article OPEN ${ }_{\text {ACCESS }}$

\begin{abstract}
Buckwheat and spelled hulls are little tested in their use in the production of functional foods. The aim of this study was to evaluate the use of hull as a functional additive in yoghurt and to determine the effect of various doses of buckwheat and spelt hull on the physicochemical, organoleptic and microbiological properties of yoghurt. The enrichment of yoghurt with buckwheat and spelled hull resulted in a decrease in total acidity and a decrease in syneresis. Addition of spelt and buckwheat hulls to yoghurts reduced the colour brightness and increased the intensity of the red and yellow colours. The highest number of S. thermophilus was found in yoghurt containing $3 \%$ buckwheat hull and the beneficial effect of the addition of hull on L. bulgaricus growth was demonstrated. The type of hull determined the flavour and odour of yoghurts. Spelt hull gave the yoghurts a more intense floury and grainy flavour than buckwheat hull.
\end{abstract}

Keywords: yoghurt, buckwheat hull, spelt hull, dietary fibre

\section{INTRODUCTION}

Food industry companies have high expectations in terms of food products that meet the consumers' demand for a healthy lifestyle. In this context, functional food plays a special role, as apart from its fundamental goal, which is nutrition, it also has the psychological or physiological impact on the human body (Menrad, 1990). In Europe, the main categories of functional food are dairy products (50\% of the market) and cereal products $(30 \%)$.Yoghurt is considered as a healthy food because it contains viable bacterial cultures. However, milk and dairy products do not contain fibre, while fibre is found in the cell wall of fruits, vegetables and cereals (Brückner-Gühmann et al., 2019). Addition of fibre of various origins as a functional component to milk-based products could contribute to better water holding capacity, improving texture and structure properties, modifying the viscosity, swelling capacity or reducing the calorific value of the finished product by acting as a bulking agent (Elleuch et al., 2011). Consumption of food containing dietary fibre may prevent cardiovascular and gastrointestinal disorders, hypertension, hypercholesterolemia, obesity and diabetes (Hashim et al., 2009; Górecka et al., 2009; Esposito et al., 2005; Krkošková et al., 2005) The average daily demand for dietary fibre is $25 \mathrm{~g}$ for women $<50$ years of age, $21 \mathrm{~g}$ for women $>50$ years, $38 \mathrm{~g}$ for men $<50$ years and $30 \mathrm{~g}$ for men $>50$ years. Most nutritionists suggest that 20-30\% of the daily fibre intake should come from soluble fibre Elleuch et al. (2011).

At present, the average global consumption of fibre is still lower than the recommended daily intake level. Thus fibre-rich by-products may be incorporated into food products as inexpensive, low-calorie bulking agents for partial replacement of flour, fat or sugar, as enhancers water and oil retention and to improve emulsion or oxidative stability. However, the percentage of fibre that may be added is finite, because it can cause undesirable changes to the colour and texture of the finished product (Elleuch et al., 2011; Hashim et al., 2009). One of solutions in preventing fibre deficiency in the human diet may be the addition of fibre to milk-based food products (Robertson et al., 2000). Yoghurt is considered a healthy food and fortifying it with dietary fibre will make it even healthier. The latest research results indicate that buckwheat deserves more interest as a valuable raw material of functional food due to the content of biologically active compounds. In buckwheat grains, dietary fibre accounts for 5 to $11 \%$, the soluble fraction content is $3-7 \%$, and the insoluble fraction is about 2 $4 \%$ Krkošková et al. (2005). Buckwheat grain is characterized by a high content of starch, protein with a favourable amino acid composition, a low content of $\alpha$ gliadin fraction and a high content of dietary fibre (Krkošková et al., 2005;
Christa et al., 2008: Dziedzic et al., 2012). Buckwheat grain is also an important source of micro- and macronutrients, as well as flavonoid compounds, mainly rutin and catechin with high antioxidant activity (Zielińska et al., 2007).

Spelt wheat is also a rich source of dietary fibre. Whole grain spelt flour contains from $8.8 \%$ to $10.1 \%$ insoluble fibre and from $1.8 \%$ to $2.0 \%$ soluble fibre (Escarnot et al., 2007). The protein found in spelt is of high value, with high nutritional qualities, since compared with common wheat, it has $20-40 \%$ higher content of amino acids, including lysine, threonine, leucine and isoleucine (Rożnowski et al., 2015). Spelt in the lipid fraction is dominated by unsaturated fatty acids, of which about $50 \%$ is linoleic acid, and slightly more than $20 \%$ oleic acid. Moreover, fats found in spelt wheat contain phytosterols and fat-soluble vitamins (A, D and E). Spelt contains many valuable macro- and micronutrients, however, different authors give different contents of individual minerals in spelt (Christa et al., 2008; Kohajdová et al., 2008).

The aim of this study was to evaluate the use of hull as a functional additive in yoghurt and to determine the effect of using various doses of buckwheat and spelt hull on the physicochemical, organoleptic and microbiological properties of yoghurt.

\section{MATERIALS AND METHODS}

\section{Materials}

Fresh milk, fat 2\% (Piątnica Dairy, Poland), micronized buckwheat hull (Młyn Niedźwiady, Poland), micronized spelt wheat hull (Młyn Niedźwiady, Poland), commercial freeze-dried yoghurt starter cultures YC-X11 consisting of Streptococcus thermophilus and Lactobacillus delbrueckii ssp. bulgaricus were supplied by Chr's Hansen (Denmark).

Fermented milk manufactured

Milks were divided into 4 parts to which was added, respectively:

$$
\begin{array}{ll}
\text { 1. } & 1.5 \% \text { spelt hull } \\
\text { 2. } & 3.0 \% \text { spelt hull } \\
\text { 3. } & 1.5 \% \text { buckwheat hull } \\
\text { 4. } & 3.0 \% \text { buckwheat hull }
\end{array}
$$

The chemical composition of spelt hull was presented in Tab 1, while the chemical composition of buckwheat hull was presented in Tab 2. Fermented milk without spelt hull and without buckwheat hull addition was used as the control sample. 
Table 1 Chemical composition of spelt hull

\begin{tabular}{lc}
\hline Composition & $\mathbf{g} / \mathbf{1 0 0 g}$ \\
\hline Fat & 2.0 \\
- saturated fat & 0.5 \\
Total Carbohydrate & 47.0 \\
- sugars & 0.2. \\
Dietary fiber & 27.0 \\
Protein & 9.0 \\
\hline & \\
Table 2 Chemical composition of buckwheat hull & $\mathbf{g} / \mathbf{1 0 0} \mathbf{g}$ \\
\hline Composition & 0.6 \\
\hline Fat & 0.2 \\
- saturated fat & 31.0 \\
Total Carbohydrate & 0.2 \\
- sugars & 81.5 \\
Dietary fiber & 4.5 \\
Protein & \\
\hline
\end{tabular}

The milk mixtures were homogenised $\left(20 \mathrm{MPa}, 60{ }^{\circ} \mathrm{C}\right.$ ) in a homogeniser (Nuoni GJJ-0.06/40, Zhejiang, China) and pasteurized in a water bath at $95{ }^{\circ} \mathrm{C}$ for 15 min and then rapidly cooled in chilled water to $45{ }^{\circ} \mathrm{C}$. After that, all the mixes were each inoculated with $1 \mathrm{~g} \mathrm{~L}^{-1}$ of yoghurt culture YC-X11. All experimental milk distributed in $100 \mathrm{ml}$ sterile plastic containers and incubated at $42{ }^{\circ} \mathrm{C}$ until a $\mathrm{pH}$ was reached to 4.7 and stored at $5{ }^{\circ} \mathrm{C}$ (Cooled Incubator ILW 115, POL-EKO Aparatura, Poland). The yoghurts were evaluated after 7 days of cold storage.

\section{Physicochemical properties}

The $\mathrm{pH}$ determination was performed with a $\mathrm{pH}$-meter (FiveEasy Mettler Toledo, Switzerland). The titratable acidity (TA) of the milk was determined according to the Soxhlet-Henkel method (Normenausschuss, 1970). Syneresis (whey separation) was determined according to the method described by SantillanUrquiza et al. (2017) with modifications (10 g sample of fermented milk was transferred into $50 \mathrm{~mL}$ plastic tube and centrifuged at LC-04 CENTRIFUGE Zenithlab, China, $1790 \mathrm{~g}$ for $10 \mathrm{~min}$ at $5^{\circ} \mathrm{C}$ ). The syneresis was estimated as the released whey over the original weight and was an average of five determinations.

Colour was analysed by colourimeter Chroma Meter CR-400 (Konica Minolta Sensing, Inc., Osaka, Japan) using the CIELAB. Determined of $\mathrm{L}^{*}, \mathrm{a}^{*}$ and $\mathrm{b}^{*}$ parameters, where $\mathrm{L}^{*}$ represents the brightness (from 0 - black to 100 - white); $\mathrm{a}^{*}$ and $-a^{*}$ redness and greenness, respectively; and $b^{*}$ and $-b^{*}$ yellowness and blueness, respectively. Before testing the instrument was calibrated on a White Calibration Plate CR-A43.

\section{Parameters of texture}

Texture was determined with the CT3 Texture Analyzer with the Texture Pro CT software (Brookfield AMETEK, USA). A TPA (Cycle Count 2) test was performed on a $100 \mathrm{~mL}$ sample of solid state yoghurt, without mixing in the container, with the following: sample - cylinder $66.00 \mathrm{~mm} \times 33.86 \mathrm{~mm}$, trigge Load $0.1 \mathrm{~N}$, test Speed $1 \mathrm{~mm} \mathrm{~s}^{-1}$, table TA-BTKIT, probe TA3/100 (acrylic cylinder $-35 \mathrm{~mm}$ diameter). The following texture parameters were determined: hardness, adhesiveness, stringiness length, cohesiveness, springiness, gumminess.

\section{Microbiological analysis}

Determination of the number of Streptococcus thermophilus (S. thermophilus) and Lactobacillus delbrueckii ssp buglaricus (L. bulgaricus) was carried out by the plate method. Microbiological property of yoghurt was determined according to the method Gao [17] with some modifications. Viable counts of $S$. thermophilus were determined on an M17 medium (Biocorp, Poland), after aerobic incubation at $37^{\circ} \mathrm{C}$ for $48 \mathrm{~h}$. Viable counts of L. bulgaricus were determined on Lactobacillus bulgaricus Agar (Base) used with acetate buffer isolation of L. bulgaricus (Sigma-Aldrich, India) and incubated anaerobically at $37^{\circ} \mathrm{C}$ for $72 \mathrm{~h}$; ). The results were expressed as $\log \mathrm{cfu} \mathrm{g}^{-1}$.

\section{Organoleptic parameters}

To assess organoleptic parameters a sensory pre-test was conducted. The organoleptic analysis was performed by a trained panel consisted of 10 women and 10 men at the age of 21-30. The panelists were served five samples at a time (in three-digit random number coded plastic cubs) and asked to rinse their mouth between samples with water. The panelists evaluated the presence of creamy milky flavour, sourness, floury flavour, grainy flavour, lactic acid odor, grainy odor (Tab 3) on a nine-point rating scale with edge markings (from $1=$ not perceptible to $9=$ extremely strong) (Barylko-Pikielna et al., 2014).
Table 3 Definitions of the attributes in descriptive organoleptic analysis of yoghurts

\begin{tabular}{ll}
\hline Attribute & Definition \\
\hline Flavor & $\begin{array}{l}\text { The taste stimulated by milk powder (none - } \\
\text { intensive) } \\
\text { Theamy - milky flavor }\end{array}$ \\
Sourness & $\begin{array}{l}\text { The intensity of flavor associated with floury (none - } \\
\text { intensive) } \\
\text { The intensity of flavor associated with cereals, (none } \\
\text { Floury flavor }\end{array}$ \\
- intensive) \\
Odoiny flavor & $\begin{array}{l}\text { The intensity of odor associated with sour milk, i.e. } \\
\text { lacid acid (none - intensive) } \\
\text { The intensity of odor associated with cereals, (none } \\
1-\text { intensive 9) }\end{array}$ \\
\hline
\end{tabular}

\section{Statistical analysis}

The obtained results were given as the mean and standard deviation was calculated statistically using the Statistica v. 13.1 software (StatSoft, USA) ANOVA was used to investigate the overall effect of the hull type and hull dose on properties of yoghurt. Significance of differences between the averages was estimated with Tukey's test $(P<0.05)$

\section{RESULTS AND DISCUSSION}

After seven days of storage at low temperature, the highest $\mathrm{pH}$ was found in yoghurt with $3 \%$ of spell hull and the lowest in the control (Tab 4). The introduction of a lower dose of hull, i.e. $1.5 \%$, did not significantly change the $\mathrm{pH}$ of yoghurt as compared with the control. Analysis of variance indicates that the type of hull did not significantly affect the $\mathrm{pH}$ value of yoghurts, but the dose was significant (Tab 5). The results are consistent with those published by Espírito Santo et al. (2012) who produced yoghurt with Passion fruit fibre. In the study by Demici et al. (2017) yoghurts with rice bran had also higher $\mathrm{pH}$ values compared with the control.

\begin{tabular}{lccccc}
\multicolumn{5}{c}{ Table 4 Values pH, total acidity [ ${ }^{\circ} \mathrm{SH}$ ], syneresis [\%], colour [L*a*b*] of yogurt } \\
\hline \multirow{2}{*}{ Properties } & \multirow{2}{*}{ Control } & $\begin{array}{c}\text { Buckwheat } \\
\text { hull } 1.5 \%\end{array}$ & $\begin{array}{c}\text { Buckwheat } \\
\text { hull 3.0\% }\end{array}$ & $\begin{array}{c}\text { Spelt hull } \\
1.5 \%\end{array}$ & $\begin{array}{c}\text { Spelt hull } \\
3.0 \%\end{array}$ \\
\hline \multirow{2}{*}{$\mathrm{pH}$} & $\begin{array}{l}4.568^{\mathrm{a}} \\
\pm 0.032\end{array}$ & $\begin{array}{c}4.582^{\mathrm{a}} \\
\pm 0.059\end{array}$ & $\begin{array}{c}4.624^{\mathrm{ab}} \\
\pm 0.087\end{array}$ & $\begin{array}{c}4.572^{\mathrm{a}} \\
\pm 0.033\end{array}$ & $\begin{array}{c}4.710^{\mathrm{b}} \\
\pm 0.020\end{array}$ \\
\hline \multirow{2}{*}{ Total } & $40.120^{\mathrm{c}}$ & $39.520^{\mathrm{bc}}$ & $34.000^{\mathrm{a}}$ & $38.240^{\mathrm{b}}$ & $32.640^{\mathrm{a}}$ \\
acidity & \pm 1.224 & \pm 0.335 & \pm 0.693 & \pm 0.780 & \pm 0.518 \\
& $96.773^{\mathrm{c}}$ & $75.503^{\mathrm{a}}$ & $75.877^{\mathrm{a}}$ & $77.250^{\mathrm{b}}$ & $78.407^{\mathrm{b}}$ \\
\multirow{2}{*}{$\mathrm{L}^{*}$} & \pm 0.689 & \pm 0.153 & \pm 0.458 & \pm 0.750 & \pm 0.362 \\
\hline \multirow{2}{*}{$\mathrm{a}^{*}$} & $-4.557^{\mathrm{d}}$ & $2.670^{\mathrm{b}}$ & $3.093^{\mathrm{c}}$ & $1.500^{\mathrm{a}}$ & $3.030^{\mathrm{c}}$ \\
& \pm 0.038 & \pm 0.036 & \pm 0.038 & \pm 0.170 & \pm 0.061 \\
\hline \multirow{2}{*}{$\mathrm{b}^{*}$} & $13.203^{\mathrm{c}}$ & $10.727^{\mathrm{b}}$ & $9.443^{\mathrm{a}}$ & $16.020^{\mathrm{d}}$ & $18.433^{\mathrm{e}}$ \\
& \pm 0.081 & \pm 0.031 & \pm 0.114 & \pm 0.130 & \pm 0.090 \\
\hline \multirow{2}{*}{ Syneresis } & $47.382^{\mathrm{c}}$ & $44.852^{\mathrm{b}}$ & $44.008^{\mathrm{ab}}$ & $43.000^{\mathrm{ab}}$ & $41.063^{\mathrm{a}}$ \\
& \pm 1.235 & \pm 1.323 & \pm 1.810 & \pm 0.727 & \pm 1.370 \\
\hline
\end{tabular}

Each value represents mean $(\mathrm{n}=15) \pm \mathrm{SD}$

Mean values in lines and denoted by different letters differ statistically significantly $(P<0.05)$

In yoghurts with buckwheat and spelt hull, the total acidity was lower than that in the control (Tab 4). Both the dose and the type of hull added significantly differentiated the total acidity (Tab 5). Introduction of a $3 \%$ addition of buckwheat hull reduced the acidity by about $6{ }^{0} \mathrm{SH}$, and of spelt hull by as much as about $7.5{ }^{0} \mathrm{SH}$ compared with the control.

Table 5 Analysis of variance (ANOVA) p-values on the type and amount on $\mathrm{pH}$ total acidity, colour $\left(\mathrm{L}^{*}, \mathrm{a}^{*}, \mathrm{~b}^{*}\right)$, syneresis, creamy- milky flavour, sourness, floury flavor, grainy flavor, lactic acid odor, grainy odor, hardness, adhesiveness, stringiness length, cohesiveness, Springiness, gumminess, S. thermophilus, L. bulgaricus of yogurt

\begin{tabular}{lccc} 
Properties & $\begin{array}{c}\text { Type of hull } \\
P \text {-values }\end{array}$ & $\begin{array}{c}\text { Amount of hull } \\
P \text {-values }\end{array}$ & $\begin{array}{c}\text { Amaunt of hull } \\
* \text { Type of hul } \\
P \text {-values }\end{array}$ \\
\hline $\mathrm{pH}$ & $\mathrm{n} . \mathrm{s} .0 .1430$ & $\uparrow 0.0016$ & n.s. 0.0519 \\
\hline Total acidity & $\uparrow 0.0007$ & $\uparrow<0.0001$ & $\uparrow 0.0001$ \\
\hline $\mathrm{L}^{*}$ & $\uparrow 0.0001$ & $\uparrow 0.0212$ & $\uparrow 0.0252$ \\
\hline $\mathrm{a}^{*}$ & $\uparrow 0.0004$ & $\uparrow 0.0002$ & $\uparrow<0.0001$ \\
\hline $\mathrm{b}^{*}$ & $\uparrow<0.0001$ & n.s. 0.5582 & $\uparrow 0.0001$ \\
\hline Syneresis & $\uparrow 0.0050$ & n.s.0.0528 & $\uparrow 0.0367$ \\
\hline Hardness & $\uparrow 0.0005$ & $\uparrow<0.0001$ & $\uparrow 0.0006$ \\
\hline Adhesiveness & $\uparrow<0.0001$ & $\uparrow 0.0243$ & $\uparrow<0.0001$ \\
\hline
\end{tabular}




\begin{tabular}{lccc}
\hline Stringiness Length & n.s.0.0505 & $\uparrow 0.0029$ & $\uparrow<0.0001$ \\
\hline Cohesiveness & $\uparrow 0.0045$ & n.s.0.5816 & n.s.0.1324 \\
\hline Springiness & n.s.0.6087 & $\uparrow 0.0171$ & n.s.0.5144 \\
\hline Gumminess & n.s.0.1910 & $\uparrow 0.0024$ & n.s.0.2916 \\
\hline Creamy-milky flavor & $\uparrow<0.0001$ & n.s.0.4265 & $\uparrow 0.0480$ \\
\hline Sourness & $\uparrow 0.0154$ & n.s.0.2678 & n.s. 0.3742 \\
\hline Floury flavor & $\uparrow<0.0001$ & $\uparrow 0.0039$ & $\uparrow 0.0396$ \\
\hline Grainy flavor & $\uparrow<0.0001$ & n.s.0.1117 & n.s. 0.2960 \\
\hline Lactic acid odor & $\uparrow<0.0001$ & n.s.0.9999 & n.s. 0.9925 \\
\hline Grainy odor & n.s.0.9576 & n.s. 0.2378 & n.s. 0.6371 \\
\hline L. bulgaricus & $\uparrow 0.0042$ & n.s. 0.1007 & n.s. 0.0929 \\
\hline S. thermophilus & $\uparrow 0.0440$ & n.s. 0.1324 & n.s. 0.1576 \\
\hline Wher Type
\end{tabular}

Where: Type of hull*Amount of hull = interaction, $\uparrow$ indicates significant effect $P<0.05$, n.s. no significant effect

Colour-space parameters ( $\mathrm{L}^{*} \mathrm{a} * \mathrm{~b} *$ ) of yoghurts were presented in Tab 4 . The $\mathrm{L}^{*}$ values of control yoghurts were significantly higher than those of yoghurts with the addition of buckwheat and spelt hull $(P<0.05)$. The $\mathrm{L}^{*}$ values decreased gradually along with increasing addition of hull dose. Similar reduction in $\mathrm{L}^{*}$ value has also been reported by Costa et al. [21] when they fortified yoghurt with cupuassu (Theobroma grandiflora) pulp. Also, Demirci et al. (2017), adding rice bran, showed a decrease in the $\mathrm{L} *$ value of yoghurts and probiotic drinks. Addition of spelt hull to yoghurts increased the proportion of red colour and intensified saturation with yellow colour in comparison with the control. Spelt grain contains, among others, colour-forming carotenoids and riboflavin. ŻukGolaszewska et al. (2018) proved that spelt grain was also characterized by a significantly higher proportion of redness $a^{*}(6.64-8.11)$ and yellowness $b^{*}$ (17.2-19.0) than that of common wheat. According to Batifoulier et al. (2006), in spelt there is $0.77-0.88 \mu \mathrm{g} / \mathrm{g}$ of riboflavin, which is characterized by intense yellow colour. The yellow-brown colour of yoghurts with the addition of triticale was also described by Tomic et al. (2017). Chromatic colour parameters in yoghurts with buckwheat hull assumed positive values for a *, indicating a significant proportion of the red colour, and positive values for $b^{*}$, indicating the proportion of the yellow colour. The high proportion of the red colour, increasing with the dose of buckwheat hull, results from a high content of phenols in the buckwheat hull. According to Zhu et al. (2014), the total content of phenolic compounds in micronized buckwheat hull is $127 \mu \mathrm{g} / \mathrm{g}$. About six flavonoids have been isolated from buckwheat grains, of which rutin predominates. Rutin, quercetin, orientin, vitexin, isovitexin, and isoorientin were identified in buckwheat hulls (Christa et al., 2009; Dietrych-Szostak et al., 1999).

Syneresis is an important defect in yoghurts caused by excessive disarray of curd stability. As it can be seen in Tab 4, yoghurts with buckwheat and spelt hulls had lower syneresis values as compared with the control. The reduction in syneresis was the most effective by the addition of spelt hull. The introduction of $1.5 \%$ spelt hull reduced syneresis by $4.0 \%$ and a higher addition of $3.0 \%$ reduced syneresis by about $6.0 \%$. The use of buckwheat hull also caused a reduction in syneresis by $2.5-3.0 \%$, however, the dose of buckwheat hull introduced was not significant. A two-way ANOVA (Tab 5) indicates that the type of hull and interactions between the dose and the type of hull had a significant effect on the extent of syneresis. This can be explained by the fact that water holding capacity of the hull is related to the porous matrix structure formed by polysaccharide chains which can hold large amounts of water through hydrogen bonds (Kethireddipalli et al., 2002). According to Zhu et al. (2014), water holding capacity of micronized buckwheat hull is $2.24 \mathrm{~g} / \mathrm{g}$, and swelling capacity is $7.48 \mathrm{~mL} / \mathrm{g}$

Huang et al. (2014) showed good moisture absorption and moisture retention capacity by a polysaccharide from buckwheat. According to Zhu, 2016, buckwheat starch gel had less syneresis than maize and wheat starch gels, even though the former had a higher content of amylose which is positively linked to syneresis.

A similar reduction in the wheat syneresis in yoghurt was reported by El-Sayed et al. (2002) adding Xanthan gum and by Hassan et al. (2015) adding cress seed mucilage or guar gum. Due to the negative chargé on the Surface of anionic hydrocolloids (e.g. CMC: Carboxy methyl cellulose) electrostatic interactions by positively charged casein micelles are established, which in turn improves stabilizing the matrix, hence decreasing the syneresis (Warren Everett et al., 2005; Weinbreck et al., 2004). In another study, yoghurts with oat concentrate were analysed and it was shown that not the oat protein, but the oat starch improved the water holding capacity in the yoghurt samples and reduced syneresis (Brückner-Gühmann et al., 2019).

After 7 days of storage, the count of $S$. thepmophilus was on average from 9.83 $9.99 \log \mathrm{cfu} \mathrm{g}^{-1}$ (Fig. 1).

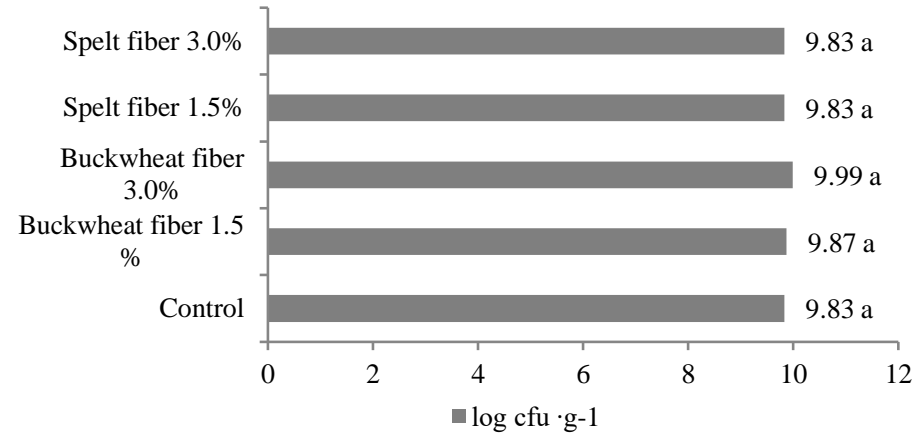

Figure 1 Viable counts of $S$. thermophilus in yogurt with fortified with hulls [log cfu $\mathrm{g}^{-1}$ ] after 7 days of cold storage. Values are means \pm S.D. for $\mathrm{n}=15$. Mean values in lines and denoted by different letters differ statistically significantly $(P$ $<0.05)$

The highest number of $S$. thermophilus was determined in buckwheat hull yoghurts. The presented number of $S$. thermophilus is comparable to the study by Demirci et al. (2017), who indicated the beneficial effect of $3.0 \%$ rice bran additive on the number of viable cells of these bacteria. In other studies, the beneficial effects of the addition of flaxseed mucilage and carboxymethylcellulose on the growth and survival of $S$. thermophilus has been demonstrated.

In this study no significant effect of the hull dose applied on the number of viable $S$. thermophilus cells (Tab 5) was found. In yoghurts with the addition of spelt hull, the number of $S$. thermophilus cells was comparable to the control sample. The number of viable $L$. bulgaricus cells depending on the type and dose of hull is presented in Figure 2. It was shown that the addition of hull had a positive effect on $L$. bulgaricus growth. A similar number of $L$. bulgaricus was found in yoghurts with rice bran in Demirci et al. (2017) and in yoghurts with the addition of Jerusalem artichoke inulins (Paseephol et al., 2009).

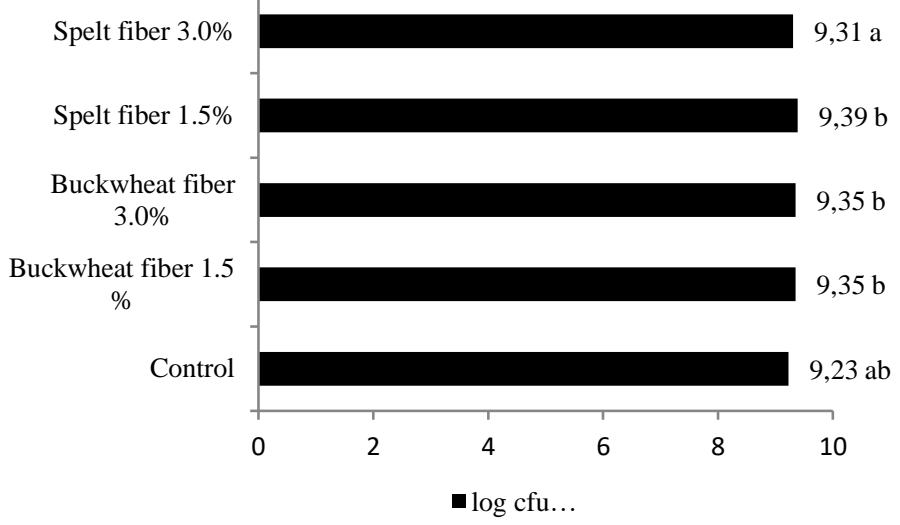

Figure 2 Viable counts of $L$. bulgaricus in yogurt with fortified with hulls [log $\mathrm{cfu} \mathrm{g}^{-1}$ ] after 7 days of cold storage. Values are means \pm S.D. for $\mathrm{n}=15$. Mean values in lines and denoted by different letters differ statistically significantly $(P$ $<0.05)$

Hardness is considered as the resistance of a sample to deformation until an external force is applied (Lal-Dar et al. 2014). The hardness results in Tab 6 showed that fortification of yoghurt with spelt and buckwheat hull at a dose of $1.5 \%$ significantly reduced the hardness compared with the control.

The use of pineapple peel fibre by Sah et al. (2016) also resulted in lower hardness of yoghurt. Specifically, pineapple peel powder incorporation resulted in lower hardness of yoghurt, resulting in a weak gel attributed to thermodynamic incompatibility between milk proteins and polysaccharides from pineapple pee powder (Corredig et al., 2011). In the study by Basiri et al. (2018) it was found that the presence of carboxy methyl cellulose (CMC) and linseed mucilage reduced the gel hardness compared with the control.

Increasing the dose of hull up to $3.0 \%$ only in case of buckwheat hull resulted in significantly greater hardness. A two-way ANOVA showed that both the type and dose of hull and the interactions of these two factors significantly affected the hardness of yoghurts (Tab 5). In this study, the highest adhesiveness value was determined in the control sample. The addition of spelt hull significantly reduced the adhesiveness of yoghurts. The addition of spelt hull did not significantly differentiate the adhesiveness of yoghurts in comparison to the control. The addition of hull influenced the stringiness length of the yoghurt gel. Significantly lower stringiness length values were obtained in yoghurts with the addition of spelt hull. In yoghurts with the addition of $3.0 \%$ of spelt hull, stringiness length similar to the control was demonstrated. The highest 
cohesiveness values were determined in yoghurts with the addition of spelt hull. There were no significant differences in the springiness of the control yoghurts and those with the addition of hull. Gumminess is a defect in which a sticky feeling is perceived in the mouth (Lal-Dar et al. 2014). The gumminess values shown in Tab 4 indicate that the addition of buckwheat or spelt hull in a dose of $1.5 \%$ decreased this defect in the yoghurt.

Table 6 Texture parameters (hardness $[\mathrm{N}]$, adhesiveness $[\mathrm{mJ}]$, stringiness length $[\mathrm{mm}]$, cohesiveness, springiness $[\mathrm{mm}]$ gumminess $[\mathrm{N}])$ of yogurt

\begin{tabular}{lccccc}
\hline Texture & Control & $\begin{array}{c}\text { Buckwheat } \\
\text { hull 1.5 \% }\end{array}$ & $\begin{array}{c}\text { Buckwheat } \\
\text { hull 3.0\% }\end{array}$ & $\begin{array}{c}\text { Spelt hull } \\
\mathbf{1 . 5 \%}\end{array}$ & $\begin{array}{c}\text { Spelt } \\
\text { hull } \\
\mathbf{3 . 0 \%}\end{array}$ \\
\hline \multirow{2}{*}{ Hardness } & $0.813^{\mathrm{b}}$ & $0.762^{\mathrm{a}}$ & $0.865^{\mathrm{c}}$ & $0.752^{\mathrm{a}}$ & $0.778^{\mathrm{ab}}$ \\
& \pm 0.032 & \pm 0.019 & \pm 0.035 & \pm 0.010 & \pm 0.013 \\
\hline \multirow{2}{*}{ Adhesiveness } & $1.100^{\mathrm{c}}$ & $0.833^{\mathrm{bc}}$ & $1.083^{\mathrm{c}}$ & $0.760^{\mathrm{b}}$ & $0.600^{\mathrm{a}}$ \\
& \pm 0.179 & \pm 0.175 & \pm 0.223 & \pm 0.051 & \pm 0.126 \\
\hline Stringiness & $10.503^{\mathrm{c}}$ & $8.685^{\mathrm{a}}$ & $10.217^{\mathrm{c}}$ & $9.662^{\mathrm{b}}$ & $9.273^{\mathrm{ab}}$ \\
Length & \pm 0.414 & \pm 1.230 & \pm 0.699 & \pm 0.367 & \pm 0.509 \\
\hline \multirow{2}{*}{ Cohesiveness } & $0.533^{\mathrm{ab}}$ & $0.522^{\mathrm{a}}$ & $0.543^{\mathrm{ab}}$ & $0.570^{\mathrm{b}}$ & $0.560^{\mathrm{ab}}$ \\
& \pm 0.021 & \pm 0.042 & \pm 0.019 & \pm 0.011 & \pm 0.022 \\
\hline \multirow{2}{*}{ Springiness } & $13.690^{\mathrm{a}}$ & $13.185^{\mathrm{a}}$ & $13.590^{\mathrm{a}}$ & $13.408^{\mathrm{a}}$ & $13.762^{\mathrm{a}}$ \\
& \pm 0.256 & \pm 0.880 & \pm 0.280 & \pm 0.295 & \pm 0.283 \\
\hline \multirow{2}{*}{ Gumminess } & $0.442^{\mathrm{ab}}$ & $0.413^{\mathrm{a}}$ & $0.468^{\mathrm{b}}$ & $0.410^{\mathrm{a}}$ & $0.438^{\mathrm{ab}}$ \\
& \pm 0.022 & \pm 0.052 & \pm 0.022 & \pm 0.025 & \pm 0.015 \\
\hline
\end{tabular}

Each value represents mean $(\mathrm{n}=15) \pm \mathrm{SD}$

Mean values in lines and denoted by different letters differ statistically significantly $(P<0.05)$

Tab 7 presents the results of the analysis of the flavour and odour of yoghurts with hull and controls. The addition of buckwheat hull reduced the intensity of milk-cream and sour flavour and increased the sense of floury and buckwhea flavour. Yoghurts with buckwheat hull had the most intense sour and buckwheat odour.

Table 7 Effect of fortification with buckwheat hull and spelt hull on organoleptic parameters of yogurt

\begin{tabular}{lccccc} 
Properties & Control & $\begin{array}{c}\text { Buckwheat } \\
\text { hull 1.5\% }\end{array}$ & $\begin{array}{c}\text { Buckwheat } \\
\text { hull 3.0\% }\end{array}$ & $\begin{array}{c}\text { Spelt hull } \\
1.5 \%\end{array}$ & $\begin{array}{c}\text { Spelt hull } \\
3.0 \%\end{array}$ \\
\hline Creamy - & $2.870^{\mathrm{ab}}$ & $2.571^{\mathrm{a}}$ & $2.143^{\mathrm{a}}$ & $3.750^{\mathrm{b}}$ & $4.625^{\mathrm{c}}$ \\
milky & \pm 0.990 & \pm 0.535 & \pm 0.378 & \pm 1.035 & \pm 1.061 \\
flavor & $5.625^{\mathrm{b}}$ & $5.357^{\mathrm{ab}}$ & $5.286^{\mathrm{ab}}$ & $4.625^{\mathrm{ab}}$ & $3.750^{\mathrm{a}}$ \\
\hline Sourness & \pm 1.685 & \pm 0.852 & \pm 0.756 & \pm 1.061 & \pm 1.389 \\
\hline Floury & $1.000^{\mathrm{a}}$ & $2.000^{\mathrm{b}}$ & $2.714^{\mathrm{b}}$ & $7.250^{\mathrm{c}}$ & $7.870^{\mathrm{c}}$ \\
flavor & \pm 0.000 & \pm 0.577 & \pm 0.488 & \pm 0.460 & \pm 0.990 \\
\hline Grainy & $1.000^{\mathrm{a}}$ & $1.571^{\mathrm{b}}$ & $1.714^{\mathrm{b}}$ & $3.750^{\mathrm{c}}$ & $4.500^{\mathrm{c}}$ \\
flavor & \pm 0.000 & \pm 0.535 & \pm 0.488 & \pm 0.460 & \pm 0.530 \\
\hline Lactic acid & $2.000^{\mathrm{a}}$ & $2.429^{\mathrm{b}}$ & $2.429^{\mathrm{b}}$ & $2.100^{\mathrm{a}}$ & $2.100^{\mathrm{a}}$ \\
odor & \pm 0.300 & \pm 0.535 & \pm 0.535 & \pm 0.230 & \pm 0.300 \\
\hline Gainy & $1.000^{\mathrm{a}}$ & $1.429^{\mathrm{ab}}$ & $1.714^{\mathrm{b}}$ & $1.500^{\mathrm{ab}}$ & $1.500^{\mathrm{ab}}$ \\
odor & \pm 0.000 & \pm 0.535 & \pm 0.488 & \pm 0.500 & \pm 0.500 \\
\hline
\end{tabular}

Each value represents mean $(n=20) \pm S D$

Mean values in lines and denoted by different letters differ statistically significantly $(P<0.05)$

Christa et al. (2008) identified condensed catechins, phenolic acids, including hydrobenzoic acids, synigric, p-hydroxy-benzoic, vanillic and p-coumaric acids in the bran-aleurone layer of buckwheat grains. Most likely, soluble oligomeric condensed catechins along with phenolic acids provided characteristic astringent buckwheat flavour.

Yoghurts with spelt hull were characterized by intensely floury flavour with a moderate proportion of grainy flavour. The intensity of these flavours effectively masked the taste of sour and milky-cream flavour. There was no sour odour in them, only a slightly perceptible grainy odour.

Brückner-Gühmann et al. (2019) also indicated a significantly perceptible oat flavour in all yoghurts with oat protein concentrate and in samples with oat protein isolate as compared with the sample fortified with SMP (skim milk powder).

Pyrroles and thiazoles have also been described as flavour compounds present in extruded flour (Parker et al., 2000). In the study by Tomic el al. (2017), grainy flavour, more intensive in triticale yoghurts compared with those fortified with wheat or oat fibre, was described as a flavour which is pleasant and typical of cereal-rich yoghurt.

\section{CONCLUSION}

The market for functional yoghurts is systematically increasing and the introduction of the addition of hull may be attractive to consumers due to the content of dietary fibre. Yoghurts with hull differ in terms of physicochemical and organoleptic properties. Fortification of yoghurts with buckwheat and spelt hull has resulted in lowering total acidity and reducing syneresis. Addition of spelt and buckwheat hulls to yoghurts reduced the colour brightness and increased the intensity of the red and yellow colours. The highest number of $S$ thermophilus was found in yoghurt containing $3 \%$ buckwheat hull and the beneficial effect of the addition of hull on $L$. bulgaricus growth was demonstrated. The type of hull determined the flavour and odour of yoghurts Spelt hull gave the yoghurts a more intense floury and grainy flavour than buckwheat hull. However, the addition of hull may be attractive to consumers due to the content of dietary fibre. Most likely, the introduction of an intensely aromatic flavour additive, such as cinnamon, apple, blueberry - would effectively mask the flavour and odour of hull uncharacteristic of yoghurt.

\section{REFERENCES}

BARYŁKO-PIKIELNA, N., MATUSZEWSKA, I. 2014. Sensoryczne Badania Żywności. Podstawy - Metody - Zastosowania [in Polish] Sensory Food Testing. Fundamentals - Methods - Applications. Wydawnictwo Naukowe PTTŻ, Krakow BASIRI, S., HAIDARY, N., SHEKARFOROUSH, S.S., NIAKOUSARI, M. 2018. Flaxseed mucilage: A natural stabilizer in stirred yogurt. Carbohydrate Polymers 187: 59-65. https://doi.org/10.1016/j.carbpol.2018.01.049

BATIFOULIER, F., VERNY, M.A., CHANLIAUD, E., RÉMÉSY, C. DEMIGNÉ, C. 2006. Variability of B vitamin concentrations in wheat grain, milling fractions and bread products. European Journal of Agronomy 25(2):163 169. https://doi.org/10.1016/j.eja.2006.04.009

BRÜCKNER-GÜHMANN, M., BENTHIN, A., DRUSCH, S. 2019. Enrichment of yoghurt with oat protein fractions: Structure formation, textural properties and sensory evaluation. Food Hydrocolloids 86:146-153. https://doi.org/10.1016/j.foodhyd.2018.03.019

CHRISTA, K., SORAL-ŚMIETANA, M. 2008. Buckwheat grains and buckwheat products - nutritional and prophylactic value of their components - a review. Czech Journal Food Science 26:153-162. https://doi.org/10.17221/1602cjfs

CORREDIG, M., SHARAFBAFI, N., KRISTO, E.P. 2011. Polysaccharideprotein interactions in dairy matrices, control and design of structures. Food Hydrocolloids 25(8):1833-1841. https://doi.org/10.1016/j.foodhyd.2011.05.014

COSTA, M.P., FRASAO, B.S., SILVA, A.C., FREITAS, MQ, FRANCO, R.M. CONTE-JUNIOR, C.A. 2015. Cupuassu (Theobroma grandiflorum) pulp, probiotic, and prebiotic: Influence on color, apparent viscosity, and texture of goat milk yogurts. Journal of Dairy Science 98(9):5995-6003 https://doi.org/10.3168/jds.2015-9738

DEMIRCI, T., AKTAS, K., SÖZERI, D., ÖZTÜRK, H.I., AKIN, N. 2017. Rice bran improve probiotic viability in yoghurt and provide added antioxidative benefits. Journal of Functional Food 36:396-403. https://doi.org/10.1016/i.jff.2017.07.019

DIETRYCH-SZOSTAK, D., OLESZEK, W. 1999. Effect of Processing on the Flavonoid Content in Buckwheat (Fagopyrum esculentum Müench) Grain. Journal of Agriculture and Food Chemistry 47: 4384-4387. https://doi.org/10.1021/jf990121m

DZIEDZIC, K., GÓRECKA, D., KUCHARSKA, M., PRZYBYLSKA, B. 2012 Influence of technological process during buckwheat groats production on dietary fibre content and sorption of bile acids. Food Research International 47(2):279283. https://doi.org/10.1016/j.foodres.2011.07.020

ELLEUCH, M., BEDIGIAN, D., ROISEUX, O., BESBES, S., BLECKER, C. ATTIA, H. 2011. Dietary fibre and fibre-rich by-products of food processing: Characterisation, technological functionality and commercial applications. Food Chemistry 124:411-421. https://doi.org/10.1016/j.foodchem.2010.06.077

EL-SAYED, E., EL-GAWAD, I.A., MURAD, H., SALAH, S. 2002. Utilization of laboratory-produced xanthan gum in the manufacture of yogurt and soy yogurt. European Food of Research and Technology 215:298-304 https://doi.org/10.1007/s00217-002-0551-9

ESCARNOT, E., AGNEESSENS, R., WATHELET, B., PAQUOT, M. 2010. Quantitative and qualitative study of spelt and wheat fibres in varying milling $\begin{array}{lll}\text { fractions. } & \text { Food Chemistry } & 122(3): 857-863\end{array}$ https://doi.org/10.1016/j.foodchem.2011.01.082

ESPÍRITO SANTO, A.P., PEREGO, P., CONVERTI, A. OLIVEIRA, M.N 2012. Influence of milk type and addition of passion fruit peel powder on fermentation kinetics, texture profile and bacterial viability in probiotic yoghurts. LWT-Food Science and Technology 47(2):393-399. https://doi.org/10.1016/j.lwt.2012.01.038

ESPOSITO, F., ARLOTTI, G., BONIFATI, A.M., NAPOLITANO, A., VITALE, D., FOGLIANO, V. 2005. Antioxidant activity and dietary fiber in durum wheat bran by products. Food Research International 38:1167-1173. https://doi.org/10.1016/j.foodres.2005.05.002

GAO, H.X., YUB, Z.L., HE, Q., TANG, S.H., ZENGA, W.C. 2018. A potentially functional yogurt co-fermentation with Gnaphalium affine. LWT-Food Science and Technology 91:423-430. https://doi.org/10.1016/j.lwt.2018.01.085 GÓRECKA, D., HĘŚ, M., SZYMANDERA-BUSZKA, K., DZIEDZIC, K. 2009 Contents of selected bioactivecomponents in buckwheat groats. Acta Scientarium 
Polonorum Technologia Alimentaria 8(2):75-83

https://doi.org/10.17306/j.afs.2016.2.16

HASHIM, I.B., KHALIL, A.H., AFIFI, H.S. 2009. Quality characteristics and consumer acceptance of yogurt fortified with date fiber. Journal of Dairy Science 92(11):5403-5407. https://doi.org/10.3168/jds.2009-2234

HASSAN, K.L., HAGGAG, H.F., ELKALYOUBI, M.H., EL-AZIZ, M., ELSAYED, M.M., SAYED, A.F. 2015. Physico-chemical properties of yoghurt containing cress seed mucilage or guar gum. Annals of Agricultural SciencesMoshtohor Science Journal 60: 21-28. https://doi.org/10.1016/j.aoas.2014.11.021 HUANG, S.R., GU, F.L., HE, X.M. 2014. Study on moisture-absorption and moisture-retention capacity of polysaccharide from the Fagopyrum dibotrys. New Chemistry of Materials 42:141-142 https://doi.org/10.4028/www.scientific.net/amr.627.138

KETHIREDDIPALLI, P., HUNG, Y.C., MCWATTERS, K.H., PHILLIPS, R.D. 2002. Effect of millingmethod (wet compared with dry) on the functional properties of cowpea (Vignaunguiculata) pastes and end product (akara) quality. Journal of Food Science 67:1. https://doi.org/10.1111/j.13652621.2002.tb11357.x

KOHAJDOVÁ, Z., KAROVIĈOVÁ, J. 2008. Nutritional value and baking applications of spelt wheat. Acta Scientarium Polonorum Technologia Alimentaria 3(7):5-14

KRKOŠKOVÁ, B., MRÁZOVÁ, Z. 2005. Prophylactic components of buckwheat. Food Research International 38:561-568 https://doi.org/10.1016/j.foodres.2004.11.009

LAL-DAR, Y., LIGHT, J.M. 2014. Food texture design and optimization. IL IFT, Chicago. https://doi.org/10.1002/9781118765616.ch1

MENRAD, K. (2003). Market and marketing of functional food in Europe. Journal of Food Engineering 56:181-188. https://doi.org/10.1016/s0260 $\underline{\text { 8774(02)00247-9 }}$

NORMENAUSSCHUSS, D. 1970. Soxhlet-Henkel determination of acidity in milk and liquid milk products. West German Standard No DIN 10316

PARKER, J.K., HASSELL, G.M.E., MOTTRAM, D.S., GUY, R.C.E. 2000 Sensory and instrumental analyses of volatiles generated during the extrusion cooking of oat flours. Journal of Agriculture and Food Chemistry 48(8)34973506. https://doi.org/10.1021/jf991302r

PASEEPHOL, T., SHERKAT, F. 2009. Probiotic stability of yoghurts containing Jerusalem artichoke inulins during refrigerated storage. Journal of Functional Food 1:311-318. https://doi.org/10.1016/j.jff.2009.07.001

ROBERTSON, J.A., DE MONREDON, F.D., DYSSELER, P., GUILLON, F., AMADO, R., THIBAULT, J.F. 2000. Hydration properties of dietary fibre and resistant starch: a european collaborative study. LWT-Food Science Technology 33(2):72-79. https://doi.org/10.1006/fstl.1999.0595

ROŻNOWSKI, J., KŁOSOWSKA, J., POLZER, P. 2015. Żywieniowe i prozdrowotne znaczenie pszenicy orkisz (Triticum spelta L.) [in Polish] Nutritional and pro-healthy properties of spelt wheat (Triticum spelta L.) Postepy Fitoterapii 16(1):45-49. https://doi.org/10.15193/zntj/2013/91/118-129

SAH, B.N.P., VASILJEVIC, T., MCKECHNIE, S., DONKOR, O.N. 2016. Physicochemical,textural and rheological properties of probiotic yogurt fortified withfibre-rich pine-apple peel powder during refrigerated storage. $L W T$ - Food of Science and Technology 65:978-986. https://doi.org/10.1016/j.lwt.2015.09.027

SANTILLAN-URQUIZA, E., MENDEZ-ROJAS, M.A., VALEZ-RUIZ, J.F. 2017. Fortification of yogurt with nano and micro sized calcium, iron and zinc, effect on the physicochemical and rheological properties. LWT-Food Science and Technology 80:462-469. https://doi.org/10.1016/j.1wt.2017.03.025

TOMIC, N., DOJNOV, B., MIOCINOVIC, J., TOMASEVIC, I., SMIGIC, N., DJEKIC, I., VUJCIC, Z. 2017. Enrichment of yoghurt with insoluble dietary fiber from triticale - A sensory perspective. LWT-Food Science and Technology 80:59-66. https://doi.org/10.1016/j.lwt.2017.02.008

WARREN EVERETT, D., MCLEOD, R.E. 2005. Interactions of polysaccharide stabilizers with casein aggregates in stirred skim-milk Yoghurt. International Dairy Journal 15:1175-1183. https://doi.org/10.1016/j.idairyj.2004.12.004

WEINBRECK, F., NIEUWENHUIJSE, H., ROBIJN, G.W., DE KRUIF, C.G. 2004. Complexation of whey proteins with carrageenan. Journal of Agriculture and Food Chemistry 52:3550-3555. https://doi.org/10.1021/jf034969t

ZHU, F. 2016. Buckwheat starch: Structures, properties, and applications. Trends Food Science and Technology https://doi.org/10.1016/j.tifs.2015.12.002

ZHU, F., DU, B., LI, R., LI, J. 2014. Effect of micronization technology on physicochemical and antioxidant properties of dietary fiber from buckwheat hulls. Biocatalysis and Agricultural Biotechnology 3:30-34 https://doi.org/10.1016/j.bcab.2013.12.009

ZIELIŃSKA， D., SZAWARA-NOWAK， D., MICHALSKA， A. 2007. Antioxidant capacity of thermally treated buckwheat. Polish Journal of Food and Nutrition Sciences 57:465-470. https://doi.org/10.1002/mnfr.201600475

ŻUK-GOŁASZEWSKA, K., MAJEWSKA, K. TYBURSKI, J., GOŁASZEWSKI, J. 2018. Physical and technological properties of kernels and flour made from spelt grown in an organic farming system in north-eastern Poland. Journal of Cereal Science 79:501-507. https://doi.org/10.1016/j.jcs.2018.01.002 